\title{
Production of cheese from donkey milk as influenced by addition of transglutaminase
}

\author{
A. G. D’Alessandro, ${ }^{* 1}$ G. Martemucci, ${ }^{1}$ P. Loizzo, ${ }^{2}$ and M. Faccia ${ }^{2}$ \\ ${ }^{1}$ Department of Agricultural and Environmental Sciences (DiSAAT), University of Bari Aldo Moro, Via G. Amendola, 70126 Bari, Italy \\ ${ }^{2}$ Department of Soil, Plant and Food Sciences (DiSSPA), University of Bari Aldo Moro, Via G. Amendola, 70126 Bari, Italy
}

\begin{abstract}
Donkey milk is characterized by low contents of total solids, fat, and caseins, especially $\kappa$-casein, which results in formation of a very weak gel upon renneting. The objective of this study was to evaluate the effect of fortification of donkey milk with microbial transglutaminase (MTGase) for cheesemaking in relation to different enzyme addition protocols (patterns, PAT). Four independent trials were performed using MTGase (5.0 $\mathrm{U} / \mathrm{g}$ of milk protein) according to the following experimental patterns: control (no MTGase addition); MTGase addition $\left(40^{\circ} \mathrm{C}\right) 15$ min before starter inoculation (PAT1); addition of MTGase to milk simultaneously with starter culture $\left(40^{\circ} \mathrm{C}\right)$ (PAT2); and MTGase addition simultaneously with rennet $\left(42^{\circ} \mathrm{C}\right)$ in acidified milk (pH 6.3) (PAT3). Evolution of $\mathrm{pH}$ during acidification, cheesemaking parameters, and proximal composition and color of cheese at $24 \mathrm{~h}$ were recorded. The protein fractions of cheese and whey were investigated by ureaPAGE and sodium dodecyl sulfate-PAGE. Addition of MTGase had no significant effect on moisture, protein, fat, or cheese yield. The addition of MTGase with rennet (PAT3) improved curd firmness compared with the control. Among the different patterns of MTGase addition, PAT3 reduced gel formation time, time between rennet addition and cheese molding, and weight loss of cheese at $24 \mathrm{~h}$. The PAT3 treatment also resulted in the lowest lightness and highest yellowness color values of the cheese. Sodium dodecyl sulfate-PAGE of cheeses revealed that MTGase modified the protein pattern in the high-molecular-weight zone (range 37-75 $\mathrm{kDa}$ ) compared with the control. Of the MTGase protocols, PAT3 showed better casein retention in cheese, as confirmed by the lanes of $\alpha$ - and $\beta$-caseins in the electropherogram of the whey, which was subtler for this protocol. In conclusion, MTGase may be used in cheese production from donkey milk to improve curd
\end{abstract}

Received March 13, 2019.

Accepted August 14, 2019.

*Corresponding author: angelagabriella.dalessandro@uniba.it firmness; MTGase should be added simultaneously with the rennet.

Key words: donkey milk, cheesemaking, transglutaminase, physicochemical evaluation, electrophoresis

\section{INTRODUCTION}

In the last decade, there has been renewed and growing interest in donkeys, in developing and developed countries, as a source of products for human consumption. Particularly in Asia, donkeys are used for meat and skin production, whereas in Europe their breeding is commonly directed to milk production (D'Alessandro and Martemucci, 2012; Kriel, 2017; Marchiș et al., 2017).

The interest of scientists in donkey milk has been fundamentally determined by its chemical-nutritional characteristics that make it a food of particular interest to certain categories of consumers. Because of its similarity to human milk (D'Auria et al., 2005), good palatability (D'Alessandro and Martemucci, 2012), and low allergenic properties (Vita et al., 2007), donkey milk is considered a useful substitute for infants affected by cow milk protein allergy (Iacono et al., 1992; Monti et al., 2012). The low allergenicity of donkey milk has been attributed to its low total protein content, low casein-to-whey fraction ratio (Cunsolo et al., 2017) and, in particular, to the low presence of $\kappa$ - and $\alpha_{\mathrm{S} 1}$-caseins, the major allergens of cow milk (Giorgis et al., 2018). Moreover, several potential health benefits in the human diet could been attributed to donkey milk, considering its activities in releasing anti-inflammatory interleukins, upregulating the immune response in aged hosts (Amati et al., 2010), the prevention of atherosclerosis (Tafaro et al., 2007), and as an antiproliferative and antitumor agents (Mao et al., 2009).

Considering these functional properties, there is interest in producing dairy products from donkey milk that are beneficial for human health. Indeed, donkey milk has been proposed as a promising base ingredient for producing yogurt-type products, such as fer- 
mented milk, yogurt, and probiotic yogurt (Coppola et al., 2002; Chiavari et al., 2005; Perna et al., 2015). The processing of donkey milk into cheese, in contrast, is very difficult, because of its poor clotting activity. The low content of total solids and caseins, especially $\kappa$-casein, does not allow formation of a firm curd on renneting, but rather induces a very weak gel (UniackeLowe and Fox, 2011; Marletta et al., 2016). Moreover, the low fat content of donkey milk (Martemucci and D'Alessandro, 2012) may negatively affect the texture and flavor of the cheese produced; it is well known that low-fat cheeses often have a diluted flavor and poor texture (Mohamed, 2015).

Limited information is available in the literature on the production of cheese from donkey milk, and the lack of coagulation using bovine chymosin has been overcome through its substitution with camel chymosin (Iannella, 2015) or the plant aspartic protease cyprosin (Sampaio, 2017), or by fortification with goat milk (Saric et al., 2016). More recently, a procedure for producing fresh donkey cheese of acceptable sensory quality was developed using calf rennet and modifying processing parameters and in-vat operations (Faccia et al., 2018).

Currently in the dairy industry, enzymatic modification of milk proteins is of interest to improve the product quality. Among the enzyme groups, microbial transglutaminase (MTGase) is one of the most important and promising tools to improve the properties of protein-based dairy products (Chang et al., 2014; Mokoonlall et al., 2016). Microbial transglutaminase (glutaminyl-peptide-amine $\gamma$-glutamyl transferase; EC 2.3.2.13) acts by catalyzing an acyl transfer reaction between a $\gamma$-carboxyamide group in protein-bound glutamine residues (acyl donor) and an $\varepsilon$-amino group in a protein-bound lysine residue (acyl acceptor), leading to covalent crosslinks of inter- or intramolecular $\varepsilon$-( $\gamma$-glutamine)-lysine isopeptidic bonds (Seguro et al., 1996). Thus, MTGase facilitates the formation of a network of high-molecular-weight peptides, inducing modification of protein and consequently of rheological functional properties, along with other qualitative product characteristics (Kuraishi et al., 2001; Gharibzahedi and Chronakis, 2018). However, variations in availability and specificity of the substrate and the conditions under which the reaction occur result in varying degrees of protein modification (Romeih and Walker, 2017).

Considering milk proteins, the cross-linking reaction of MTGase occurs preferentially on caseins compared with whey proteins, due to their flexibility, low degree of tertiary structure, and the absence of disulfide bonds in $\alpha_{\mathrm{S}^{-}}$and $\beta$-casein (Bonisch et al., 2006; Tsevdou et al., 2013). Since 1998, MTGase has been recognized as a safe material for human intake by the US Food and Drug Administration as "generally recognized as safe" (GRAS; Gerrard et al., 2000; Gharibzahedi et al., 2019). As indicated by the European Parliament Directive 2000/13 EC, MTGase is considered an adjunct technology similar to rennet (Food Safety Authority of Ireland, 2016).

In the dairy sector, the most common application of MTGase is in the production of fermented milks, such as yogurt and other acid-induced milk gels (Romeih and Walker, 2017; Gharibzahedi and Chronakis, 2018). Several studies have focused on MTGase application in cheese manufacture, with the major purpose of increasing cheese yield and enhancing the quality of low-fat cheese (reviewed by Romeih and Walker, 2017). To the best of our knowledge, no study to date has reported on the application of MTGase for processing cheese from pure donkey milk. Therefore, the main objective of this study was to determine whether MTGase has a fortification effect on donkey milk for cheesemaking. Thus, we evaluated different processes of MTGase addition with respect to the evolution of $\mathrm{pH}$ during acidification of donkey milk, certain cheesemaking parameters, physicochemical characteristics of the cheeses produced, and electrophoresis of cheese and whey.

\section{MATERIALS AND METHODS}

\section{Milk Collection and Analysis}

The experiment was conducted during the spring season (April to May). Donkey milk was obtained from a herd of adult lactating jennies of the Martina Franca donkey breed, reared under semi-extensive conditions on a farm located in southern Italy (Apulia region), and routinely milked twice a day by mechanical milker (D'Alessandro and Martemucci, 2012).

Morning and evening bulk milk was taken and analyzed in duplicate for pH (pH meter GLP 21, Crison, Alella, Barcelona, Spain), gross composition (infrared spectroscopy by MilkoScan FT1, Foss, Hillerød, Denmark), and ash content (incineration in a muffle furnace at $530^{\circ} \mathrm{C}$ ). Total protein, fat, lactose, and ash contents $( \pm \mathrm{SD})$ of raw milk were $2.29 \pm 0.08 \%, 0.25 \pm 0.03 \%$, $6.76 \pm 0.07 \%$, and $0.39 \pm 0.04 \%$, respectively.

\section{Small-Scale Cheesemaking Process}

In a pilot study, 4 independent small-scale trials were performed at the dairy laboratories of the Department of Agricultural and Environmental Science, University of Bari (Bari, Italy).

In each trial, $4 \mathrm{~L}$ of donkey milk was divided into 4 equal portions to produce cheese, according to the experimental design for MTGase optimization (Figure 


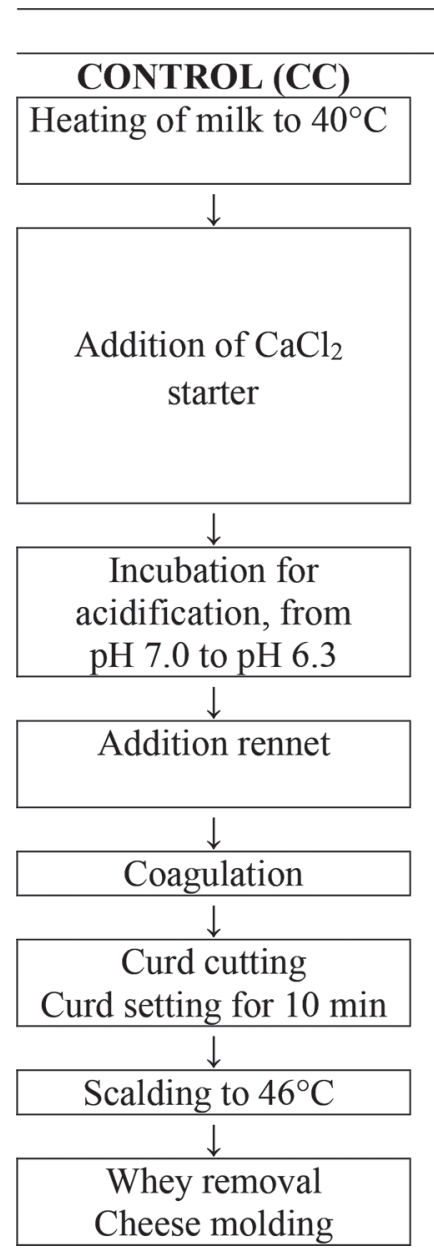

Cheesemaking specificities for

\begin{tabular}{|c|c|c|c|}
\hline CONTROL (CC) & PAT1 & PAT2 & \multirow{2}{*}{$\begin{array}{c}\text { PAT3 } \\
\text { Heating of milk to } 40^{\circ} \mathrm{C}\end{array}$} \\
\hline Heating of milk to $40^{\circ} \mathrm{C}$ & \multirow[t]{2}{*}{ Heating of milk to $40^{\circ} \mathrm{C}$} & Heating of milk to $40^{\circ} \mathrm{C}$ & \\
\hline \multicolumn{3}{|l|}{$\downarrow$} & \\
\hline \multirow[b]{2}{*}{$\begin{array}{c}\text { Addition of } \mathrm{CaCl}_{2} \\
\text { starter }\end{array}$} & \multirow{3}{*}{$\begin{array}{c}\text { Addition of } \mathrm{CaCl}_{2} \\
\quad \text { MTGase } \\
\downarrow \\
\text { Incubation for } 15 \mathrm{~min} \\
\downarrow \\
\text { Addition starter }\end{array}$} & \multirow{3}{*}{$\begin{array}{l}\text { Addition of } \mathrm{CaCl}_{2} \\
\text { starter } \\
\text { MTGase }\end{array}$} & \multirow[t]{3}{*}{$\begin{array}{r}\text { Addition of } \mathrm{CaCl}_{2} \\
\text { starter }\end{array}$} \\
\hline & & & \\
\hline$\downarrow$ & & & \\
\hline $\begin{array}{l}\text { Incubation for } \\
\text { acidification, from } \\
\text { pH } 7.0 \text { to } \mathrm{pH} 6.3\end{array}$ & \multirow[t]{2}{*}{$\begin{array}{c}\text { Incubation for } \\
\text { acidification to } \mathrm{pH} 6.3\end{array}$} & \multirow[t]{2}{*}{$\begin{array}{c}\text { Incubation for } \\
\text { acidification to } \mathrm{pH} 6.3\end{array}$} & \multirow[t]{2}{*}{$\begin{array}{c}\text { Incubation for } \\
\text { acidification to } \mathrm{pH} 6.3\end{array}$} \\
\hline$\downarrow$ & & & \\
\hline Addition rennet & \multirow[t]{2}{*}{ Addition of rennet } & \multirow[t]{2}{*}{ Addition of rennet } & \multirow[t]{2}{*}{$\begin{array}{c}\text { Addition of MTGase } \\
\text { rennet }\end{array}$} \\
\hline$\downarrow$ & & & \\
\hline Coagulation & \multirow[t]{2}{*}{ Coagulation } & \multirow[t]{2}{*}{ Coagulation } & \multirow[t]{2}{*}{ Coagulation } \\
\hline$\downarrow$ & & & \\
\hline Curd cutting & \multirow{2}{*}{$\begin{array}{c}\text { Curd cutting } \\
\text { Curd setting for } 10 \mathrm{~min}\end{array}$} & \multirow{2}{*}{$\begin{array}{c}\text { Curd cutting } \\
\text { Curd setting for } 10 \mathrm{~min}\end{array}$} & \multirow{2}{*}{$\begin{array}{c}\text { Curd cutting } \\
\text { Curd setting for } 10 \mathrm{~min}\end{array}$} \\
\hline$\frac{\text { Curd setting for } 10 \mathrm{~min}}{\downarrow}$ & & & \\
\hline Scalding to $46^{\circ} \mathrm{C}$ & \multirow[t]{2}{*}{ Scalding to $46^{\circ} \mathrm{C}$} & \multirow[t]{2}{*}{ Scalding to $46^{\circ} \mathrm{C}$} & \multirow[t]{2}{*}{ Scalding to $46^{\circ} \mathrm{C}$} \\
\hline$\downarrow$ & & & \\
\hline $\begin{array}{l}\text { Whey removal } \\
\text { Cheese molding }\end{array}$ & $\begin{array}{l}\text { Whey removal } \\
\text { Cheese molding }\end{array}$ & $\begin{array}{l}\text { Whey removal } \\
\text { Cheese molding }\end{array}$ & $\begin{array}{l}\text { Whey removal } \\
\text { Cheese molding }\end{array}$ \\
\hline
\end{tabular}

Figure 1. Flowchart for the manufacturing of cheese as control (no microbial transglutaminase, MTGase) and in relation to the experimental patterns (PAT1 to PAT3) of MTGase (5.0 U/g of milk protein) addition.

1). The first portion was used to produce control cheese (CC) without enzyme addition. The other 3 portions of milk were treated with MTGase.

All donkey milk cheeses were processed according to the protocol reported in a previous study (Faccia et al., 2018) with certain modifications, as follows: final milk $\mathrm{pH}$ before rennet addition (6.3), use of microbial rennet (instead of calf rennet), and smaller size of curd cutting $(1.0$ vs. $2.0 \mathrm{~cm})$. Moreover, to evaluate the effect of MTGase addition on cheese draining, the cheeses were not salted at the end of the cheesemaking process. Thus, the protocol was as follows. Milk was supplemented with calcium chloride $(0.3 \mathrm{~g} / \mathrm{L})$ and tempered to $40^{\circ} \mathrm{C}$ before inoculation with a commercial starter culture of Streptococcus thermophilus (Teknomilk, TKM srl, Gioia del Colle, BA, Italy) at a concentration of $0.01 \mathrm{~g} / \mathrm{L}$ milk.

The milk acidification progress was monitored by $\mathrm{pH}$ measurement using a portable $\mathrm{pH}$ meter (model $\mathrm{pH}$ 110; Eutech Instruments, Milan, Italy) and the time required to reach $\mathrm{pH} 6.3$ was recorded. When the milk reached $\mathrm{pH}$ 6.3, liquid microbial rennet (Micro-Lactis 220 TL; $220 \mathrm{IMCU} / \mathrm{mL}$, Linea Lactis s.r.l., Gioia del Colle, Bari, Italy) was added $(0.1 \mathrm{~mL} / \mathrm{L}$ of milk $)$ to milk heated to $42^{\circ} \mathrm{C}$ in a thermostatic water bath. The milk was allowed to coagulate at a constant temperature of $42^{\circ} \mathrm{C}$. Coagulation behavior was monitored by observation of milk clotting. The cutting time for each type of curd was established empirically by evaluating the separation and clarity of the whey and resistance to crushing with a teaspoon. At this time, viscosity was determined using a vibro viscometer (SV-10; 0.3-10,000 mPa.s; A\&D Company Limited, Tokyo, Japan) on an aliquot $\left(40 \mathrm{~mL}\right.$ at $\left.42^{\circ} \mathrm{C}\right)$ of each acidified and renneted milk sample. Viscosity was determined first at the addition of the rennet, then at gel formation time, and finally after $30 \mathrm{~min}$ from the gel formation.

The milk gel was cut with a cheese wire knife into $1.0-\mathrm{cm}$ cubes while heating slowly to $46^{\circ} \mathrm{C}$ and left to settle for $10 \mathrm{~min}$. Then, the whey was drained and the 
curd was placed into a cheese mold with light manual pressure and weighed for yield calculation.

The same procedure was used for each type of cheese with the exception of MTGase addition, which was performed at different phases of the procedure, according to the following experimental patterns (Figure 1): (1) addition of MTGase to milk with calcium chloride at $40^{\circ} \mathrm{C}$ and incubated for 15 min before addition of starter culture (PAT1); (2) addition of MTGase to milk simultaneously with calcium chloride and starter culture $\left(40^{\circ} \mathrm{C}\right)$ (PAT2); and (3) addition of MTGase simultaneously with rennet to acidified milk ( $\mathrm{pH} 6.3$, $\left.42^{\circ} \mathrm{C}\right)$ (PAT3). In the experimental protocols, MTGase (Activa YG, Ajinomoto Foods Europe SAS, Hamburg, Germany) was used at $5.0 \mathrm{U} / \mathrm{g}$ of milk protein (nominal enzymatic activity of $100 \mathrm{U} / \mathrm{g}$; data supplied by the manufacturer).

Each cheese was weighed and cheese yield calculated as actual yield (percentage weight of the cheese divided by the initial weight of the milk) and as cheese yield on a DM basis. The $\mathrm{pH}$ was measured at 3 internal locations (in the cheese center) using a portable $\mathrm{pH}$ meter (model pH 110; Eutech Instruments) equipped with a penetrating glass electrode. The cheeses were then stored in plastic boxes at $4 \pm 1^{\circ} \mathrm{C}$ for $24 \mathrm{~h}$.

\section{Physicochemical Analyses of Cheese}

After $24 \mathrm{~h}$ of refrigeration $\left(2-4^{\circ} \mathrm{C}\right)$, color coordinates (lightness, $\mathbf{L}^{*}$; redness, $\mathbf{a}^{*}$; yellowness, $\mathrm{b}^{*}$ ) were detected on the external and internal surfaces of each cheese using a HunterLab MiniScanTM XE Spectrophotometer (model 4500/L, 45/0 LAV, 3.20-cm-diameter aperture, $10^{\circ}$ standard observer, focusing at $25 \mathrm{~mm}$, illuminant D65/10; Hunter Associated Laboratory Inc., Reston, VA), taking 3 measurements for each location, where each measurement was the mean of 3 readings. Representative samples of each cheese were then frozen $\left(-20^{\circ} \mathrm{C}\right)$ for proximal composition analyses: moisture by oven-dry method (IDF 4A; IDF, 1982); fat by Soxhlet extraction (IDF, 2001); and total protein by Kjeldahl method (IDF 20B:1993; IDF, 1993).

\section{Electrophoresis}

The protein fractions of milk, wheys, and cheeses were investigated by urea-PAGE according to the method of Andrews (1983) and by SDS-PAGE as reported by Harper et al. (1989). All reagents and solvents were purchased from Bio-Rad (Richmond, CA). For ureaPAGE, the samples were dissolved in $0.625 \mathrm{~mol} / \mathrm{L}$ Tris$\mathrm{HCl}$ buffer at $\mathrm{pH} 6.8$ containing $6 \mathrm{~mol} / \mathrm{L}$ urea and 1 $\mathrm{mL} / \mathrm{L}$ mercaptoethanol; for SDS-PAGE, the buffer was the same, except for addition of $20 \mathrm{~g} / \mathrm{L}$ SDS. In both cases, the samples were loaded onto a discontinuous gel $(16 \times 18 \mathrm{~cm})$ and run using a LKB2001-100 vertical apparatus LKB equipped with a Multitemp II cooling bath and an EPS 500/400 Electrophoresis Power Supply (LKB, Vienna, Austria). After running, the gels were stained with "blue silver" as described by Candiano et al. (2004) and destained in water. Protein bands were identified by taking into consideration their molecular weight and by comparison with literature data (Guo et al., 2007; Chianese et al., 2010; Saric et al., 2016). Images of destained gels were uploaded on an image analysis system and scanned for densitometry analysis using Quantity One software (BioRad, Hercules, CA). The optical densities were expressed as the ratio of the quantity to the total area of the bands. All analyses were performed in duplicate.

\section{Statistical Analysis}

Statistical analysis was performed using SPSS version 21.0 (SPSS/IBM Corp., New York, NY). All data were subjected to one-way ANOVA to determine differences between samples. Significant differences were compared by Bonferroni test at a level of $P<0.05$.

\section{RESULTS AND DISCUSSION}

\section{Effect of MTGase on Milk Acidification}

The protocol of MTGase addition influenced $(P<$ 0.01 ) the milk acidification rate, calculated from the time of starter inoculation to reaching $\mathrm{pH} 6.3$ (Table 1). In PAT2 and PAT1, where MTGase was added together with starter and after 15 min, respectively, acidification was faster than that of PAT3 and CC $(P<0.01)$.

Figure 2 shows the milk acidification curves for each of the cheesemaking protocols. In all cases, in the first $90 \mathrm{~min}$, the $\mathrm{pH}$ showed only a slight decrease, probably corresponding to the bacterial growth lag phase. After this time, $\mathrm{pH}$ decreased more quickly in PAT1 and PAT2 and reached the target value of 6.30 more quickly compared with that of PAT3 and CC $(P<$ 0.01). As expected, the acidification rate of PAT3 was very similar to that of CC, because MTGase had not yet been included in milk (it was added with rennet after $\mathrm{pH} 6.30$ was reached). A faster decrease in $\mathrm{pH}$ with MTGase addition is reported in some studies on yogurt preparation (Neve et al., 2001; Darnay et al., 2015; Jooyandeh et al., 2015). In particular, Neve et al. (2001) hypothesized that the development of a cross-linked protein network by MTGase may bring the Streptococcus thermophilus starter cells into closer physical contact with growth-stimulating soluble small peptides. Because we used Streptococcus thermophilus 
Table 1. Cheesemaking parameters, loss of weight, and proximal composition at $24 \mathrm{~h}$ of cheese from pure donkey milk in relation to different patterns of microbial transglutaminase (MTGase; $5.0 \mathrm{U} / \mathrm{g}$ of milk protein) addition (mean $\pm \mathrm{SEM}$ )

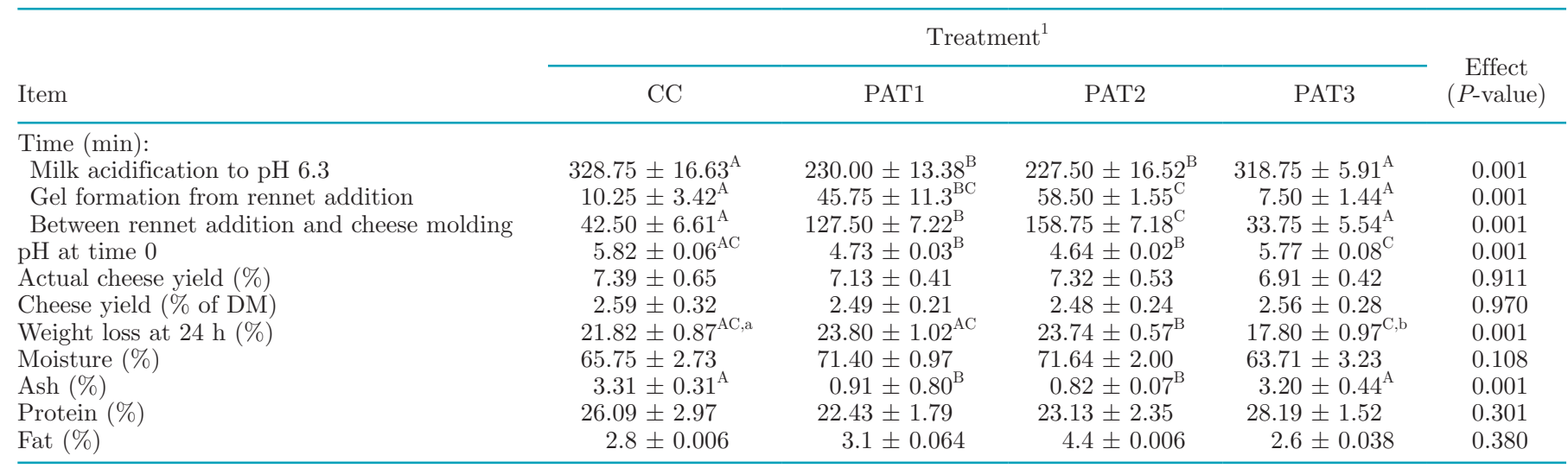

$\overline{\mathrm{a}, \mathrm{b}}$ Means within rows with different superscript letters are significantly different $(P<0.05)$.

${ }^{\mathrm{A}-\mathrm{C}}$ Means within rows with different superscript letters are significantly different $(P<0.01)$.

${ }^{1}$ Treatments: $\mathrm{CC}=\left(\right.$ control) no MTGase addition; PAT1 = addition of MTGase with calcium chloride $\left(40^{\circ} \mathrm{C}\right)$, incubation for 15 min before addition of starter culture; PAT2 = addition of MTGase to milk simultaneously with calcium chloride and starter culture $\left(40^{\circ} \mathrm{C}\right)$; PAT3 $=$ addition of MTGase simultaneously with rennet in acidified milk $\left(\mathrm{pH} 6.3 ; 42^{\circ} \mathrm{C}\right)$.

as a starter on raw milk, these stimulating peptides could have been released by the endogenous microflora, supporting faster growth of the starter in PAT1 and PAT2. Alternatively or in addition, formation of the cross-linked protein network could have reduced the buffering capacity of the milk, allowing the lactic acid deriving from lactose fermentation to lower the $\mathrm{pH}$ more rapidly.

\section{Cheesemaking Process Parameters, Yield, and Composition}

In PAT3, where MTGase was added to acidified milk simultaneously with rennet, gel formation occurred in the shortest time, being different $(P<0.01)$ from that of PAT1 and PAT2 and similar $(P>0.05)$ to that of CC (Table 1). We hypothesized that addition of MTGase before rennet addition caused a competing reaction against the rennet activity. This finding is in agreement with other studies (Bonisch et al., 2008; Ozer et al., 2012) in which a delay in coagulation time occurred following preincubation of MTGase with cheese milk before rennet addition.

The shortest gel formation time observed in PAT3 corresponded to the highest curd viscosity. Starting from the addition of the rennet, viscosity increased suddenly from 1.10 to $40.4 \mathrm{mPa} \cdot \mathrm{s}$ at gel formation time and reaching $58.0 \mathrm{mPa} \cdot \mathrm{s}$ after $30 \mathrm{~min}$. Both PAT1 and PAT2 showed a more delayed formation of weak gels with low viscosity $(1.84-2.60 \mathrm{mPa} \cdot \mathrm{s})$ that reached 4.22 and $4.57 \mathrm{mPa} \cdot \mathrm{s}$ after $30 \mathrm{~min}$. The viscosity recorded for the CC protocol was intermediate (9.91 and 25.9 $\mathrm{mPa} \cdot \mathrm{s}$, respectively, at gel formation and after $30 \mathrm{~min}$ ).
Overall, these results indicate that MTGase addition, following the PAT3 protocol, was effective in improving the clotting behavior of donkey milk. From a technological viewpoint, the simultaneous addition of MTGase and rennet had a positive synergistic action on curd formation and firming.

Again, PAT3 resulted in the shortest time between rennet addition and cheese molding compared with PAT1 and PAT2 $(P<0.01$; Table 1$)$ and was similar to that of CC. The differences could be due to more

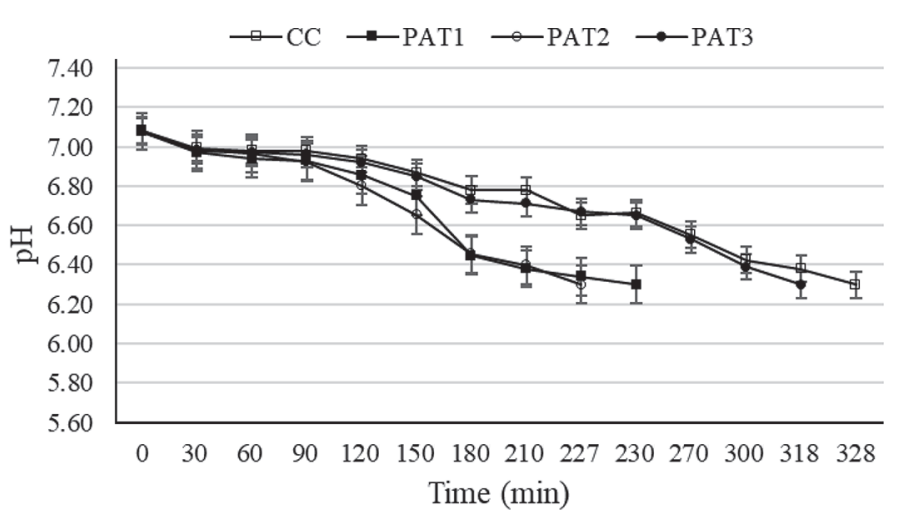

Figure 2. Evolution of $\mathrm{pH}$ (bars represent SE) during acidification of donkey milk inoculated with starter culture (Streptococcus thermophilus, $0.01 \mathrm{~g} / \mathrm{L} ; 40^{\circ} \mathrm{C}$ ) following cheese production protocols: $\mathrm{CC}$ $=$ no microbial transglutaminase (MTGase) addition (control); PAT1 $=$ addition of MTGase with calcium chloride $\left(40^{\circ} \mathrm{C}\right)$ and incubation for $15 \mathrm{~min}$ before addition of starter culture; PAT2 = addition of MTGase to milk simultaneously with calcium chloride and starter culture $\left(40^{\circ} \mathrm{C}\right)$; PAT3 = addition of MTGase simultaneously with rennet in acidified milk $\left(\mathrm{pH} 6.3 ; 42^{\circ} \mathrm{C}\right)$. 
rapid separation of the whey from the curd observed in PAT3.

The cheese $\mathrm{pH}$ was lower $(P<0.01)$ in PAT1 and PAT2 than in PAT3 and CC (Table 1), which may be attributable to the greater time needed to complete the cheesemaking procedure. Cheese yield was not influenced by the cheesemaking protocol. The actual cheese yield ranged from $6.91 \%$ in PAT3 to $7.39 \%$ in CC, and cheese yield on a DM basis ranged from $2.84 \%$ in PAT2 to $3.63 \%$ in PAT3 (Table 1). The weight loss of cheese after $24 \mathrm{~h}$ of storage was lowest in PAT3 compared with PAT1 and PAT2 $(P<0.01)$ and $\mathrm{CC}(P<0.05$; Table 1).

Overall, the cheese yield obtained in this study using pure donkey milk, regardless of the protocol used, was higher than that reported by other researchers (Iannella, 2015; Sampaio, 2017) and confirms the result of our previous study (Faccia et al., 2018).

The use of MTGase did not improve cheese yield but did affect gel formation and its properties, such as viscosity and syneresis, in relation to the time of its introduction, whether before (PAT1 and PAT2) or together (PAT3) with rennet addition.

Understanding the mechanism of how the enzyme acted in the different protocols was not an objective of this study. However, the effect of the enzyme was probably a consequence of modified casein micelle structure and micelle-micelle interactions, because it is known that transglutaminase facilitates intermolecular cross-linking of micellar caseins (Schorsch et al., 2000; Huppertz et al., 2007; Huppertz and De Kruif, 2008).

Ultimately, we can hypothesize that MTGase addition using the PAT3 protocol acted in synergy with rennet, leading to a protein network with a small mesh size that improved coagulation parameters and the strength of the curd. This process may have also involved syneresis; the tendency for whey separation is primarily linked to dynamics of the casein network rather than to the mobility of the water molecules (van Vliet and Walstra, 1994).

Considering the chemical composition of cheese, we found no differences in moisture, protein, or fat contents in cheese at $24 \mathrm{~h}$ of storage among the different protocols (Table 1$)$. The ash content was higher $(P<$ $0.01)$ in PAT3 and CC than in PAT1 and PAT2 cheeses.

In studies of the inclusion of MTGase in yogurtmaking milk, no significant effect on the gross chemical composition has been reported (Farnsworth et al., 2006; Dinkei, 2012; Aloğlua and Öner, 2013; Romeih et al., 2014). In this study, albeit without differences in gross composition among the protocols, PAT3 had lower actual cheese yield and less moisture than $\mathrm{CC}$, because the addition of MTGase with rennet increased syneresis, with a higher loss of whey and, thus, a lower weight of curd and lesser weight loss after $24 \mathrm{~h}$ of storage. This was confirmed by its higher value of cheese yield on a DM basis, which, although not significant, indicated better retention of milk proteins. Moreover, the highest protein content, in PAT3 $(28.19 \%)$, corresponded to the lowest fat value $(0.26 \%)$; conversely, the lowest protein content, in PAT2 $(23.13 \%)$, corresponded to the highest fat percentage $(0.44 \%)$. Taking into account that MTGase can enclose 1 to $2 \%$ more protein in cheese due to the formation of high-molecular-weight protein polymers (Gauche et al., 2008; Karzan et al., 2016), we could speculate that the different times of enzyme addition in PAT3 and PAT2 resulted in differences in the protein network, affecting the relationship between fat and moisture contents in the cheeses. In general, it is known that fat and moisture act as fillers in the cheese casein matrix (Sánchez-Macías et al., 2010).

\section{Cheese Color}

Color represents an important sensory characteristic of cheese and it is influenced by different factors. Considering that the addition of MTGase can affect color (Darnay et al., 2017), we evaluated the color of cheese to verify whether the effect of MTGase on the protein network influenced this parameter. Our results showed that MTGase had no effect on redness $\left(a^{*}\right)$ but affected the lightness $\left(\mathrm{L}^{*}\right)$ and yellowness $\left(\mathrm{b}^{*}\right)$ values of the cheese (Table 2). On the external surface, the PAT3 protocol had the lowest $\mathrm{L}^{*}$ value $(P<0.01)$ compared with PAT2, and the highest $(P<0.05) \mathrm{b}^{*}$ value compared with CC cheese. On the internal surface, the differences among the cheeses were more marked and PAT3 had lower $\mathrm{L}^{*}(P<0.01)$ and higher $\mathrm{b}^{*}(P<0.01)$ values than PAT1, PAT2, and CC cheeses. According to some authors (Sheehan et al., 2005; Khosrowshahi et al., 2006), differences observed in cheese lightness are associated with moisture content. Therefore, compared with that of PAT1, PAT2, and CC cheeses, the lower $\mathrm{L}^{*}$ in PAT3 cheese could be due to its lower moisture content with fewer free droplets, leading to a lesser degree of light scattering.

In a study on semi-hard cheese from cow milk, the positive effect of MTGase on yellowness was attributed to the cross-linking activity of the enzyme, leading to entrapment of fat-soluble $\beta$-carotene (Darnay et al., 2017). In this study, we cannot explain the effect of PAT3 on yellowness, considering the low fat content of donkey milk.

\section{Electrophoresis}

Figures 3 and 4 show the SDS-PAGE results of the cheese and whey samples, respectively. In cheese, the 
Table 2. External and internal color analysis ${ }^{1}$ of cheese from pure donkey milk in relation to different patterns of microbial transglutaminase (MTGase; $5.0 \mathrm{U} / \mathrm{g}$ of milk protein) addition (mean $\pm \mathrm{SEM}$ )

\begin{tabular}{|c|c|c|c|c|c|}
\hline Item & \multicolumn{4}{|c|}{ Treatment $^{2}$} & $\begin{array}{c}\text { Effect } \\
(P \text {-value })\end{array}$ \\
\hline $\mathrm{a}^{*}$ & $-1.91 \pm 0.26$ & $-1.97 \pm 0.18$ & $-2.10 \pm 0.10$ & $-2.48 \pm 0.19$ & 0.242 \\
\hline $\mathrm{b}^{*}$ & $5.77 \pm 0.41^{\mathrm{a}}$ & $6.79 \pm 0.27$ & $6.93 \pm 0.33$ & $7.92 \pm 0.41^{\mathrm{b}}$ & 0.020 \\
\hline \multicolumn{6}{|c|}{ Internal surface } \\
\hline $\mathrm{b}^{*}$ & $6.79 \pm 0.37^{\mathrm{A}}$ & $6.74 \pm 0.09^{\mathrm{A}}$ & $6.90 \pm 0.12^{A}$ & $8.72 \pm 0.28^{\mathrm{B}}$ & 0.001 \\
\hline
\end{tabular}

${ }_{\mathrm{a}, \mathrm{b}}$ Means within a row with different superscript letters are significantly different $(P<0.05)$.

${ }^{\mathrm{A}, \mathrm{B}}$ Means within a row with different superscript letters are significantly different $(P<0.01)$.

${ }^{1} \mathrm{~L}^{*}=$ lightness; $\mathrm{a}^{*}=$ redness; $\mathrm{b}^{*}=$ yellowness.

${ }^{2}$ Treatments: $\mathrm{CC}=\left(\right.$ control) no MTGase addition; PAT1 $=$ addition of MTGase with calcium chloride (40 $\left.{ }^{\circ} \mathrm{C}\right)$ and incubation for 15 min before addition of starter culture; PAT2 = addition of MTGase to milk simultaneously with calcium chloride and starter culture $\left(40^{\circ} \mathrm{C}\right)$; PAT3 $=$ addition of MTGase simultaneously with rennet in acidified milk $\left(\mathrm{pH} 6.3 ; 42^{\circ} \mathrm{C}\right)$.

most significant qualitative differences among the samples were observed in the high-molecular-weight zone $(37-75 \mathrm{kDa})$. The bands in this area were much more intense in the experimental cheeses than in CC. Some were high-molecular-weight whey proteins, whereas those that were not detected in $\mathrm{CC}$ could be newly formed protein aggregates produced by MTGase. It is likely that such compounds derived from aggregation of some $\alpha$ - and $\beta$-caseins, because the corresponding bands in the experimental samples appeared slightly less intense. In the remaining area of the gel, $\mathrm{CC}$ and PAT3 samples appeared to be very similar, as were PAT1 and PAT2 samples. The differences between the 2 pairs are mainly quantitative: in particular, some lowmolecular-weight bands were more prominent in CC and PAT3, whereas PAT1 and PAT2 contained slightly higher amounts of $\beta-\mathrm{LG}$ and $\alpha-\mathrm{LA}$ and lysozyme. The better casein retention in PAT3 compared with the other experimental cheeses was confirmed by the electropherogram of the whey, in which lanes WPAT1 and WPAT2 presented greater amounts of $\alpha$ - and $\beta$-casein (Figure 4). The urea-PAGE patterns of the cheeses (Figure 5) confirmed the results obtained by SDS-PAGE and made it possible to detect further differences between the pairs CC-PAT3 and PAT1-PAT2. In particular, an important difference was found in the upper zone of the gel, where CC and PAT3 showed a diffuse band that was absent in the other 2 samples. However, this cannot be ascribed to the action of MTGase because it was present in the CC sample.

Overall, the differences detected between experimental and $\mathrm{CC}$ cheeses were subtle, particularly in terms of protein aggregation induced by MTGase. This can probably be ascribed to the scarce presence of $\kappa$-casein and the high presence of whey proteins in donkey milk.
In fact, $\kappa$-casein is highly involved in crosslinking in milk, whereas whey proteins are less involved (Gauche et al., 2008). Moreover, the crosslinking action of the enzyme could have been influenced by the temperature applied during cheesemaking. The mechanism underly-

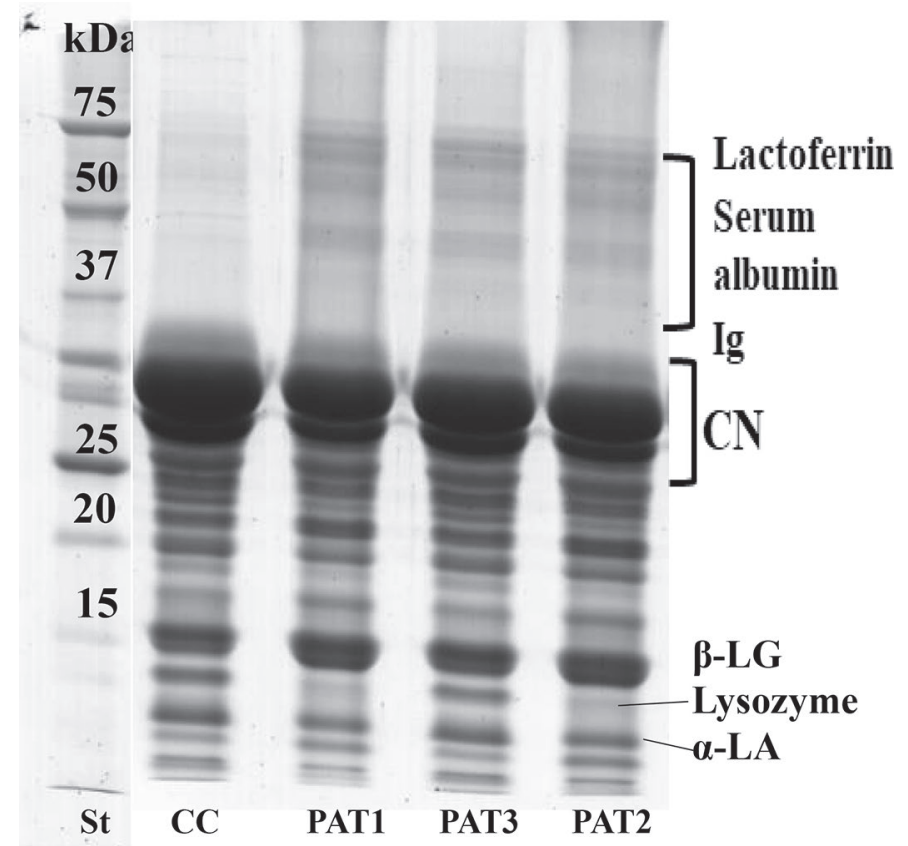

Figure 3. Sodium dodecyl sulfate-PAGE of cheese from pure donkey milk in relation to different patterns (PAT) of microbial transglutaminase (MTGase; $5.0 \mathrm{U} / \mathrm{g}$ of milk protein) addition: $\mathrm{CC}=$ (control) no MTGase addition; PAT1 = addition of MTGase with calcium chloride $\left(40^{\circ} \mathrm{C}\right)$ and incubation for 15 min before addition of starter culture; PAT2 = addition of MTGase to milk simultaneously with calcium chloride and starter culture $\left(40^{\circ} \mathrm{C}\right)$; PAT3 = addition of MTGase simultaneously with rennet in acidified milk $\left(\mathrm{pH} 6.3 ; 42^{\circ} \mathrm{C}\right) . \mathrm{St}=$ molecular weight standard. 

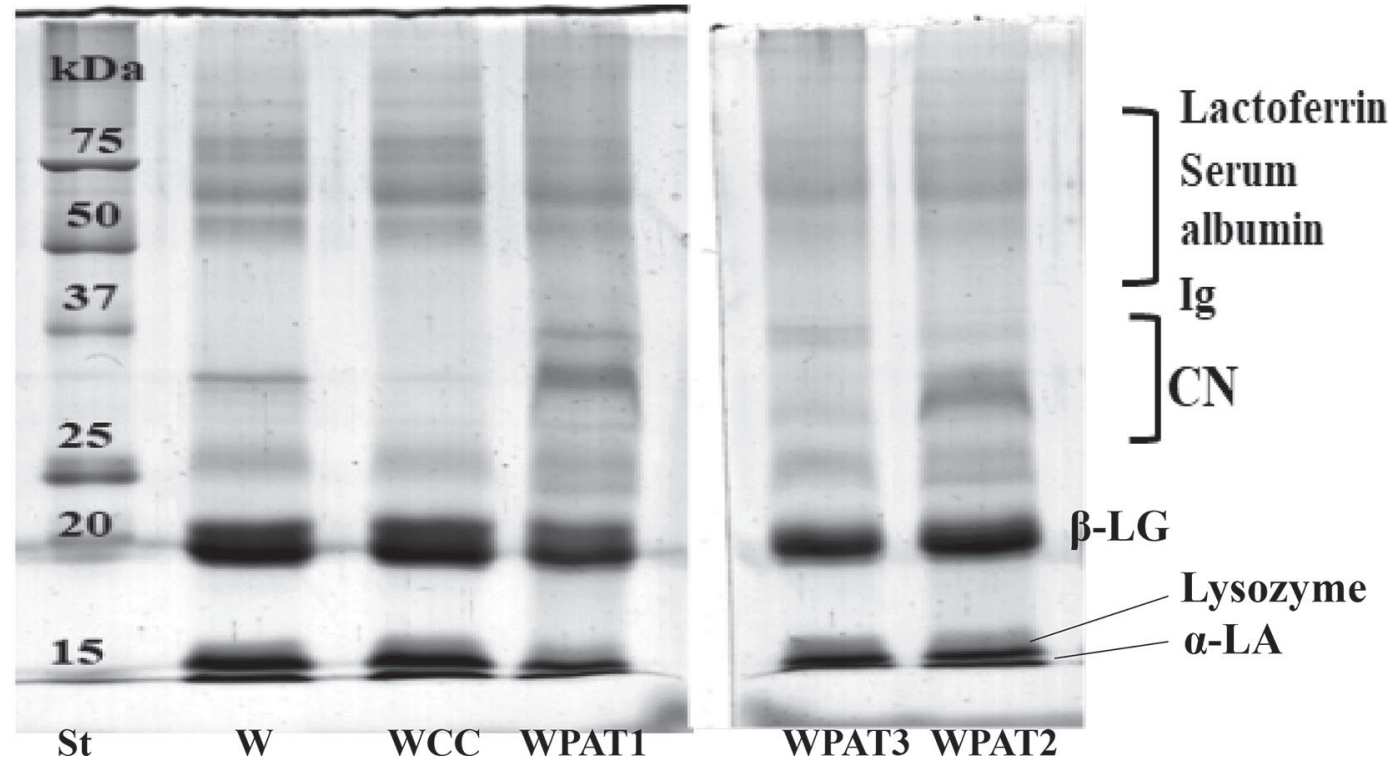

Figure 4. Sodium dodecyl sulfate-PAGE of donkey milk whey (W) and cheese whey after extraction of the curd in relation to different patterns (PAT) of microbial transglutaminase (MTGase; $5.0 \mathrm{U} / \mathrm{g}$ of milk protein) addition: WCC = no MTGase addition (control); WPAT1 = addition of MTGase with calcium chloride $\left(40^{\circ} \mathrm{C}\right)$ and incubation for 15 min before addition of starter culture; WPAT2 = addition of MTGase to milk simultaneously with calcium chloride and starter culture $\left(40^{\circ} \mathrm{C}\right)$; WPAT3 = addition of MTGase simultaneously with rennet in acidified milk $\left(\mathrm{pH} 6.3 ; 42^{\circ} \mathrm{C}\right)$. St $=$ molecular weight standard.

ing the effect of MTGase added with rennet needs to be better defined.

In conclusion, MTGase can be applied in cheese production from donkey milk to improve curd firmness.

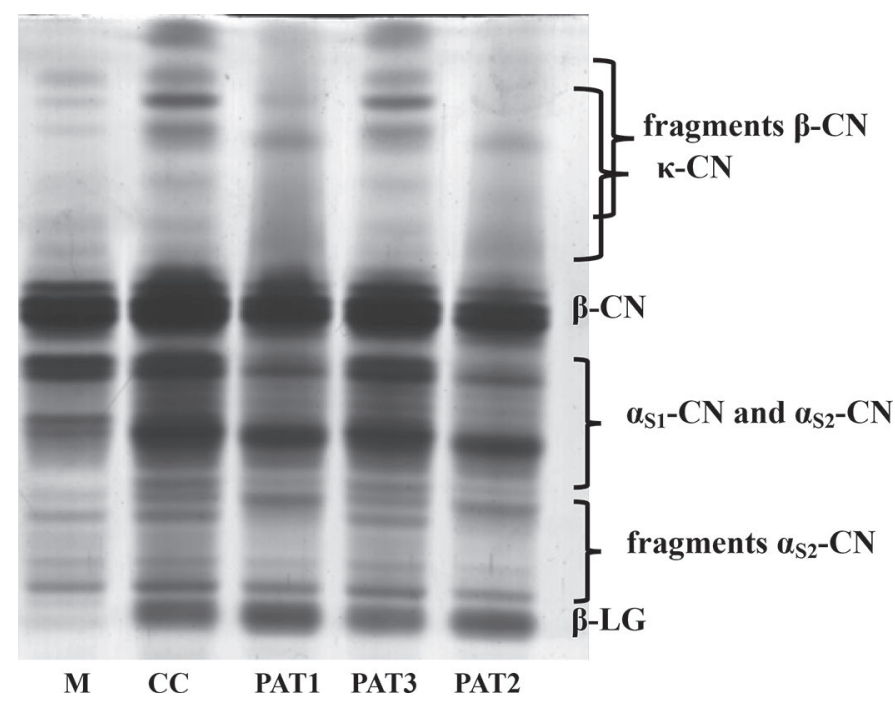

Figure 5. Urea-PAGE of donkey milk (M) and cheese in relation to different patterns (PAT) of microbial transglutaminase (MTGase; 5.0 $\mathrm{U} / \mathrm{g}$ of milk protein) addition: $\mathrm{CC}=$ (control) no MTGase addition; PAT1 $=$ addition of MTGase with calcium chloride $\left(40^{\circ} \mathrm{C}\right)$ and incubation for $15 \mathrm{~min}$ before addition of starter culture; PAT2 = addition of MTGase to milk simultaneously with calcium chloride and starter culture $\left(40^{\circ} \mathrm{C}\right)$; PAT3 = addition of MTGase simultaneously with rennet in acidified milk $\left(\mathrm{pH} 6.3 ; 42^{\circ} \mathrm{C}\right)$.
However, it is recommended that the enzyme be added simultaneously with rennet. Further studies are needed to explore the effects induced by addition of MTGase on the organoleptic characteristics of cheese and in terms of a strategy to design new dairy products.

\section{ACKNOWLEDGMENTS}

The authors declare no conflicts of interest. The study was funded by University of Bari Aldo Moro (Italy).

\section{REFERENCES}

Aloğlua, H. Ş., and Z. Öner. 2013. The effect of treating goat's milk with transglutaminase on chemical, structural, and sensory properties of labneh. Small Rumin. Res. 109:31-37.

Amati, L., G. Marzulli, M. Martulli, A. Tafaro, F. Jirillo, V. Pugliese, and G. Martemucci. 2010. Donkey and goat milk intake and modulation of the human aged immune response. Curr. Pharm. Des. 16:864-869.

Andrews, A. T. 1983. Proteinases in normal bovine milk and their action on caseins. J. Dairy Res. 50:45-55.

Bonisch, M. P., H. C. Heidebach, and U. Kulozik. 2008. Influence of transglutaminase protein cross-linking on the rennet coagulation of casein. Food Hydrocoll. 22:288-297.

Bonisch, M. P., A. Tolkach, and U. Kulozik. 2006. Inactivation of an indigenous transglutaminase inhibitor in milk serum by means of UHT-treatment and membrane separation techniques. Int. Dairy J. 16:669-678.

Candiano, G., M. Bruschi, L. Musante, L. Santucci, G. M. Ghiggeri, B. Carnemolla, P. Orecchia, L. Zardi, and P. G. Rigetti. 2004. Blue silver: A very sensitive colloidal Coomassie G-250 staining for proteome analysis. Electrophoresis 25:1327-1333. 
Chang, C. H., B. H. Kong, and X. H. Zhao. 2014. Quality attributes of the set-style yoghurt from whole bovine milk as affected by an enzymatic oxidative cross-linking. CYTA J. Food 12:249-255.

Chianese, L., M. G. Calabrese, P. Ferranti, R. Mauriello, G. Garro, C. De Simone, M. Quarto, F. Addeo, G. Cosenza, and L. Ramunno. 2010. Proteomic characterization of donkey milk "caseome". J. Chromatogr. A 1217:4834-4840

Chiavari, C., F. Coloretti, M. Nanni, E. Sorrentino, and L. Grazia. 2005. Use of donkey's milk for a fermented beverage with lactobacilli. Lait 85:481-490.

Coppola, R., E. Salimei, M. Succi, E. Sorrentino, M. Nanni, P. Ranieri, R. Belli Blanes, and L. Grazia. 2002. Behaviour of Lactobacillus rhamnosus strains in ass's milk. Ann. Microbiol. 52:55-60.

Cunsolo, V., R. Saletti, V. Muccilli, S. Gallina, A. Di Francesco, and S. Foti. 2017. Proteins and bioactive peptides from donkey milk: The molecular basis for its reduced allergenic properties. Food Res. Int. 99:41-57.

D'Alessandro, A. G., and G. Martemucci. 2012. Lactation curve and effects of milking regimen on milk yield and quality, and udder health in Martina Franca jennies (Equus asinus). J. Anim. Sci. 90:669-681.

D'Auria, E., C. Agostoni, M. Giovannini, E. Riva, R. Zetterström, R. Fortin, G. F. Greppi, L. Bonizzi, and P. Roncada. 2005. Proteomic evaluation of milk from different mammalian species as a substitute for breast milk. Acta Paediatr. 94:1708-1713.

Darnay, L., F. Králik, G. Oros, Á. Koncz, and F. Firtha. 2017. Monitoring the effect of transglutaminase in semi-hard cheese during ripening by hyperspectral imaging. J. Food Eng. 196:123-129.

Darnay, L., A. Len, Á. Koncz, L. Friedrich, and L. Rosta. 2015. Small angle neutron scattering study of nanostructural changes in microbial transglutaminase-treated lowfat yogurt during fermentation. Food Sci. Biotechnol. 24:2125-2128.

Dinkei, N. 2012. The influence of transglutaminase treatment on functional properties of strained yoghurt. J. Anim. Vet. Adv. 11:22382246.

Faccia, M., G. Gambacorta, G. Martemucci, G. Natrella, and A. G. D'Alessandro. 2018. Technological attempts at producing cheese from donkey milk. J. Dairy Res. 85:327-330.

Farnsworth, J. P., J. Li, G. M. Hendricks, and M. R. Guo. 2006. Effects of transglutaminase treatment on functional properties and probiotic culture survivability of goat milk yogurt. Small Rumin. Res. 65:113-121.

Food Safety Authority of Ireland. 2016. Labelling of food enzymes. Accessed January 2019.https://www.fsai.ie/legislation/food _legislation/food_enzymes/labelling_of_food_enzymes.html \#Labelling \% 20of\%20food\%20enzymes \% 20and \% 20food $\% 20$ enzyme $\% 20$ preparations $\% 20$ intended $\% 20$ for $\% 20$ sale $\% 20$ to $\% 20$ the $\% 20$ final $\% 20$ consumer

Gauche, C., J. T. C. Vieira, P. J. Ogliari, and L. M. T. Bordignon. 2008. Cross-linking of milk whey proteins by transglutaminase. Process Biochem. 43:788-794.

Gerrard, J. A., M. P. Newberry, M. Ross, A. J. Wilson, S. E. Fayle, and S. Kavale. 2000. Pastry lift and croissant volume as affected by microbial transglutaminase. J. Food Sci. 65:312-314.

Gharibzahedi, S. M. T., and I. S. Chronakis. 2018. Crosslinking of milk proteins by microbial transglutaminase: Utilization in functional yogurt products. Food Chem. 245:620-632.

Gharibzahedi, S. M. T., S. Yousefi, and I. S. Chronakis. 2019. Microbial transglutaminase in noodle and pasta processing. Crit. Rev. Food Sci. Nutr. 59:313-327. https://doi.org/10.1080/10408398 .2017.1367643

Giorgis, V., G. Rolla, A. Raie, M. Geuna, M. Boita, C. Lamberti, S. Nebbia, M. Giribaldi, M. G. Giuffrida, L. Brussino, F. Corradi, B. Bacco, S. Gallo Cassarino, S. Nicola, and L. Cavallarin. 2018. A case of work-related donkey milk allergy. J. Investig. Allergol. Clin. Immunol. 28:197-199.

Guo, H. Y., K. Pang, X. Y. Zhang, L. Zhao, S. W. Chen, M. L. Dong, and F. Z. Ren. 2007. Composition, physiochemical properties, nitrogen fraction distribution, and amino acid profile of donkey milk. J. Dairy Sci. 90:1635-1643.
Harper, J., M. Meyer, D. Knighton, and J. Lelievre. 1989. Effects of whey proteins on the proteolysis of Cheddar cheese slurries. (A model for the maturation of cheese made from ultrafiltered milk). J. Dairy Sci. 72:333-341.

Huppertz, T., and C. G. De Kruif. 2008. Structure and stability of nanogel particles prepared by internal cross-linking of casein micelles. Int. Dairy J. 18:556-565.

Huppertz, T., M. A. Smiddy, and C. G. De Kruif. 2007. Biocompatible micro-gel particles from cross-linked casein micelles. Biomacromolecules 8:1300-1305.

Iacono, G., A. Carroccio, F. Cavataio, G. Montalto, M. Soresi, and V. Balsamo. 1992. Use of ass' milk in multiple food allergy. J. Pediatr. Gastroenterol. Nutr. 14:177-181.

Iannella, G. 2015. Donkey cheese made through pure camel chymosin. Afr. J. Food Sci. 9:421-425.

IDF (International Dairy Federation). 1982. Cheese and processed cheese, determination of the total solid content (reference method). IDF Standard 4A. IDF, Brussels, Belgium.

IDF (International Dairy Federation). 1993. Determination de la teneur en azote Total Nitrogen (NT) (Kjeldahl Method). IDF Standard 20B. IDF, Brussels, Belgium.

IDF (International Dairy Federation). 2001. Milk and Milk ProductsExtraction Methods for Lipids and Liposoluble Compounds. IDF Standard 172. IDF, Brussels, Belgium.

Jooyandeh, H., S. A. Mortazavi, P. Farhang, and V. Samavati. 2015. Physicochemical properties of set-style yoghurt as effect by microbial transglutaminase and milk solids contents. J. Appl. Environ. Biol. Sci. 4:59-67.

Karzan, T. M., H. S. Nawal, and T. A. Ashna. 2016. The effect of microbial transglutaminase enzyme on some physicochemical and sensory properties of goat's whey cheese. Int. Food Res. J. 23:688693

Khosrowshahi, A., A. Madadlou, M. E. Z. Mousavi, and Z. EmamDjomeh. 2006. Monitoring the chemical and textural changes during ripening of Iranian white cheese made with different concentrations of starter. J. Dairy Sci. 89:3318-3325.

Kriel, G. 2017. Donkey production: Great economic opportunity or potential minefield? Farmer's Weekly 2017:36-40.

Kuraishi, C., K. Yamazaki, and Y. Susa. 2001. Transglutaminase: Its utilization in the food industry. Food Rev. Int. 17:221-246.

Mao, X., J. Gu, Y. Sun, S. Xu, X. Zhang, H. Yang, and F. Ren. 2009. Anti-proliferative and anti-tumour effect of active components in donkey milk on A549 human lung cancer cells. Int. Dairy J. 19:703-708.

Marchis, Z., A. Odagiu, A. Coroian, I. Oroian, and C. Raducu. 2017. Testing the influence of the environmental climatic factors upon donkey milk quality. Sci. Work Ser. C Vet. Med. 63:155-163.

Marletta, D., F. Tidona, and S. Bordonaro. 2016. Donkey milk proteins: Digestibility and nutritional significance. In Milk Proteins: From Structure to Biological Properties and Health Aspects. I. Gigli, ed. IntechOpen, https://doi.org/10.5772/62597.

Martemucci, G., and A. G. D'Alessandro. 2012. Fat content, energy value and fatty acid profile of donkey milk during lactation and implications for human nutrition. Lipids Health Dis. 11:113-126.

Mohamed, A. G. 2015. Low-fat cheese: A modern demand. Int. J. Dairy Sci. 10:249-265.

Mokoonlall, A., L. Sykora, J. Pfannstiel, S. Nöbel, J. Weiss, and J. Hinrichs. 2016. A feasibility study on the application of a laccasemediator system in stirred yoghurt at the pilot scale. Food Hydrocoll. 60:119-127.

Monti, G., S. Viola, C. Baro, F. Cresi, P. A. Tovo, G. Moro, M. P. Ferrero, A. Conti, and E. Bertino. 2012. Tolerability of donkey's milk in 92 highly-problematic cow's milk allergic children. J. Biol. Regul. Homeost. Agents 26:75-82.

Neve, H., P. Chr. Lorenzen, A. Mautner, E. Schlimme, and K. J. Heller. 2001. Effects of transglutaminase treatment on the production of set skim milk yoghurt: Microbiological aspects. Kieler Milchw. Forsch. 53:347-361.

Ozer, B., C. Guyot, and U. Kulozik. 2012. Simultaneous use of transglutaminase and rennet in milk coagulation: Effect of initial $\mathrm{pH}$ and renneting temperature. Int. Dairy J. 24:1-7. 
Perna, A., I. Intaglietta, A. Simonetti, and E. Gambacorta. 2015. Donkey milk for manufacture of novel functional fermented beverages. J. Food Sci. 80:S1352-1359.

Romeih, E., M. Abdel-Hamid, and A. Awad. 2014. The addition of buttermilk powder and transglutaminase improves textural and organoleptic properties of fat-free buffalo yogurt. Dairy Sci. Technol. 94:297-309.

Romeih, E., and G. Walker. 2017. Recent advances on microbial transglutaminase and dairy application. Trends Food Sci. Technol. 62:133-140.

Sampaio, P. N. S. 2017. Optimization of clotting donkey milk using an aspartic protease from Cynara cardunculus flowers. J. Adv. Dairy Res. 5:190. https://doi.org/10.4172/2329-888X.1000190.

Sánchez-Macías, D., M. Fresno, I. Moreno-Indias, N. Castro, A. Morales-delaNuez, S. Álvarez, and A. Argüello. 2010. Physicochemical analysis of full-fat, reduced fat, and low-fat artisan-style goat cheese. J. Dairy Sci. 93:3950-3956.

Saric, L. C., B. M. Saric, A. I. Mandic, M. S. Hadnadev, J. M. Gubic, I. L. Milovanovic, and J. M. Tomic. 2016. Characterization of extra-hard cheese produced from donkeys' and caprine milk mixture. Dairy Sci. Technol. 96:227-241.

Schorsch, C., H. Carrie, and I. T. Norton. 2000. Cross-linking casein micelles by a microbial transglutaminase: Influence of cross-links in acid-induced gelation. Int. Dairy J. 10:529-539.
Seguro, K., Y. Kumazawa, C. Kuraishi, H. Sakamoto, and M. Motoki. 1996. E-( $\gamma$-glutamyl) lysine moiety in crosslinked casein is an available source of lysine for rats. J. Nutr. 126:2557-2562.

Sheehan, J. J., T. Huppertz, M. G. Hayes, A. L. Kelly, T. P. Beresford, and T. P. Guinee. 2005. High pressure treatment of reduced-fat Mozzarella cheese: Effects on functional and rheological properties. Innov. Food Sci. Emerg. Technol. 6:73-81.

Tafaro, A., T. Magrone, F. Jirillo, G. Martemucci, A. G. D'Alessandro, L. Amati, and E. Jirillo. 2007. Immunological properties of donkey's milk: Its potential use in the prevention of atherosclerosis. Curr. Pharm. Des. 13:3711-3717.

Tsevdou, M. S., E. G. Eleftheriou, and P. S. Taoukis. 2013. Transglutaminase treatment of thermally and high pressure processed milk: Effects on the properties and storage stability of set yoghurt. Innov. Food Sci. Emerg. Technol. 17:144-152.

Uniacke-Lowe, T., and P. F. Fox. 2011. Equid milk. Pages 518-529 in Encyclopedia of Dairy Sciences. 2nd ed. J. W. Fuquay, P. F. Fox and P. L. H. McSweeney, ed. Academic Press, San Diego, CA.

van Vliet, T., and P. Walstra. 1994. Water in casein gels; how to get it out or keep it in. J. Food Eng. 22:75-88.

Vita, D., G. Passalacqua, G. Di Pasquale, L. Caminiti, G. Crisafulli, I. Rulli, and G. B. Pajno. 2007. Ass's milk in children with atopic dermatitis and cow's milk allergy: Crossover comparison with goat's milk. Pediatr. Allergy Immunol. 18:594-598. 